\title{
STATUS REPRODUKSI DAN POTENSI SAPI SONOK DI KABUPATEN PAMEKASAN
}

\author{
Reproduction Status and Potential of Sonok Cattle in Pamekasan District
}

Nurlaila. S., Kurnadi. B, Zali. M, dan Nining H.

Faculty of Animal Science, Madura University

J1. Raya Panglegur Km 3,5, Pamekasan, East Java, Indonesia 69371

Email : zali@unira.ac.id

\begin{abstract}
The method of data collection was done by interviewing farmers directly (respondents) using questionnaires. There were 4 subdistricts those were being the targets of the population, namely from 13 subdistricts in Pamekasan District were the locations for maintaining sonok cattle. Cluster proporsive sampling was determined by the sample of respondents, that was the method of sampling by setting characteristics those were in accordance with the objectives and criteria, namely all of the Sonok cattle those were kept by farmers in 4 subdistricts in Pamekasan District which were the centers for Sonok cattle breeding. The reproduction status of Sonok cattle in Pamekasan District was quite good. The first age of marriage was $23.40 \pm 4.17, S$ / C $1.59 \pm 0.53$ times, the distance between young calf $14.50 \pm 1.83$ months, and the value of reproductive efficiency (ER) is $90.51 \%$. The natural increase (NI) value of Sonok cattle in Pamekasan District in 2014 was 9.55\%, the value of net replacement rate (NRR) was 101, 48\%. The estimation result of Sonok cattle output was $8.24 \%$. Madura cattle population dynamics at the Sonok cattle Nursery Center in Pamekasan District in the period of 2013 to 2017 experienced an average increase of $7.98 \%$ annually. The estimated results of the population dynamics from 2018 to 2022 were expected to increase annually by $9.18 \%$. It was concluded that Sonok cattle in Pamekasan District still had the potential to increase the population and the output value was lower than NI (5.06\% vs. $15.81 \%)$.
\end{abstract}

Keywords : Pamekasan District, Reproduction Status, Natural Increase Value, Sonok Cattle, Questionnaire

\section{PENDAHULUAN}

Sapi Madura adalah salah satu bangsa sapi asli Indonesia, banyak didapatkan di Pulau Madura. Sapi Madura dapat digunakan sebagai sapi pedaging, sapi Sonok dan sapi Karapan. Salah satu kelebihan sapi Madura adalah tahan terhadap kondisi pakan yang berkualitas rendah (Musofie, et al., 1992). Menurut Kutsiyah (2015) Sapi Sonok adalah sepasang sapi Madura berjenis kelamin betina unggul. Pemelihraan sapi sonok dilakukan dengan semi intensif oleh peternak di Kabupaten Pamekasan. Beberapa tahap penyeleksian terjadi sebelum menjadi sapi Sonok, sapi tersebut mengalami sehingga sapi Sonok layak untuk disebut sebagai sapi bibit. Tahapan yang dilalui yakni sapi taccek dan sapi pajangan. Sapi Sonok berasal dari Desa Dempo Kecamatan Pasean Kabupaten Pamekasan. Pada saat itu selain digunakan untuk membajak sawah, sapi juga dimanfaatkan sebagai media silaturahmi dan sarana hiburan bagi masyarakat setempat atau sebagai alat untuk kegiatan budaya daerah salah satunya kolom taccek.

Keberadaan sapi Sonok menciptakan teknologi pemurnian untuk membibitkan sapi
Madura yang berkualitas serta menjaga kelestariandan meningkatkan tampilan atau performan sapi Madura. Keunggulan sapi Sonok dibandingkan sapi Madura pada umumnya yakni dari aspek genetik telah dilaksanakan seleksi secara ketat (silsilah reproduksi), mulai dari pemilihan tetua, seleksi performan individu hingga tes hasil keturunannya dan aspek pemeliharaannya tergolong pola pemeliharaan optimal. Performa sapi jantan unggul menjadi pemacek dan sapi pejantan yang digunakan sebagai sumber semen beku yang dipelihara di Balai Besar Inseminasi Buatan, sementara performa sapi betina unggulan dijadikan sebagai sapi Sonok/betina produktif sapi Madura unggul. Penelitian ini merupakan pengembangan dari penelitian sebelumnya terkait dengan silsilah reproduksi sapi Madura di Kabupaten Pamekasan. Kabupaten Pamekasan merupakan kawasan pengembangan peternakan, salah satunya adalah pengembangan ternak sapi Sonok yang memberikan sumbangan terbesar dalam penyediaan bibit unggul untuk sapi Madura potong. Berdasarkan hasil uraian diatas, maka penelitian ini penting dilakukan untuk dijadikan salah satu acuan untuk mengetahui status 
reproduksi dan potensi sapi Sonok di Kabupaten Pamekasan Madura.

\section{MATERI DAN METODE}

Penelitian ini dilaksanakan di Kabupaten Pamekasan yakni di Kecamatan Pakong, Pasean, Waru dan Batumarmar mulai Februari sampai dengan September 2018.

\section{Materi}

Materi yang digunakan dalam penelitian ini adalah peternak sapi Sonok di Kabupaten Pamekasan. Jumlah responden 100 orang dan jumlah sapi 291 ekor yang diambil dari 4 Kecamatan yang merupakan sentra pembibitan sapi Sonok. Peralatan yang digunakan adalah kamera dan alat tulis.

\section{Metode}

Metode pengambilan data dilakukan dengan wawancara langsung kepada peternak (responden) dengan menggunakan kuesioner. Lokasi target populasi ada empat kecamatan dari 13 kecamatan di Kabupaten Pamekasan yang merupakan lokasi pemeliharaan sapi Sonok. Penentuan sampel responden penelitian secara Cluster Proporsive Sampling, yaitu cara pengambilan sampel dengan menetapkan ciri yang sesuai dengan tujuan dan kriteria yaitu seluruh ternak sapi Sonok yang dipelihara peternak di empat kecamatan di Kabupaten Pamekasan yang merupakan sentra pembibitan sapi sonok.

Terdapat beberapa kriteria sampel dalam penelitian ini adalah 1) peternak yang berlokasi di sentra pembibitan sapi Sonok, 2) Peternak yang memiliki sapi Sonok induk, 3) Sapi Sonok induk telah berproduksi minimal 2 kali. Data yang diambil pada penelitian ini adalah 1) Jumlah sapi yang dimasukkan dan dikeluarkan selama setahun terakhir; 2) identitas responden yang meliputi umur responden, lama beternak, pendidikan, pekerjaan, pemilikan lahan, jumlah kepemilikan ternak; 3) Manajemen pemeliharaan masingmasing ternak; 4) Sifat-sifat reproduksi yang meliputi umur pertama kali dikawinkan (bulan), umur melahirkan pertama kali (bulan), service per conception pada setiap kebuntingan, tipe kelahiran dan jenis kelamin pedet pada setiap kelahiran, jarak antar kelahiran (bulan), lama tetua jantan dan betina digunakan dalam pembiakan, dan sistem perkawinan.

Data yang diperoleh disajikan dalam bentuk rataan, standar deviasi dan persentase. Analisis data yang digunakan untuk estimasi dinamika populasi adalah sebagai berikut: Efisiensi Reproduksi (ER), PertambahanAlami/ Natural Increase (NI), Nilai Net Replacement Rate (NRR), Estimasi Output dan Dinamika Populasi.

\section{HASIL DAN PEMBAHASAN}

\section{Struktur Populasi Sapi Sonok}

Stuktur populasi ternak merupakan susunan silsilah sekumpulan ternak dalam hal ini ternak sapi sonok. Struktur populasi ternak dapat dibedakan atas jenis kelamin dan umur, dimana umur ternak sapi terbagi atas dewasa (sapi yang telah berproduksi, umumnya berumur dua tahun atau lebih), muda (sapi lepas sapih yang berumur antara satu hingga dua tahun dan belum berproduksi), dan anak/pedet (anak sapi yang berumur 0 hingga 12 bulan atau anak sapi yang masih menyusui pada induknya). Struktur populasi ternak sapi Sonok di Kabupaten Pamekasan berdasarkan hasil penelitian lapangan yang telah dilakukan dapat dilihat pada Tabel 1 dan Tabel 2.

Tabel 1. Struktur Populasi Sapi Madura Betina di Sentra Pembibitan Sapi Sonok Kabupaten Pamekasan

\begin{tabular}{lcccccccc}
\hline \multirow{3}{*}{ JenisKelamin } & \multicolumn{7}{c}{ Umur Ternak Sapi Sonok } \\
\cline { 2 - 9 } & \multicolumn{2}{c}{ Anak } & \multicolumn{7}{c}{ Muda } & Dewasa & Jumlah \\
\cline { 2 - 9 } & $\mathrm{N}$ & $\%$ & $\mathrm{~N}$ & $\%$ & $\mathrm{~N}$ & $\%$ & $\mathrm{~N}$ & $\%$ \\
\hline Betina & 15.316 & 26,11 & 19.229 & 32,78 & 24.101 & 41,09 & 58.646 & 100
\end{tabular}

Sumber : Dinas Ketahanan Pangan dan Peternakan (2017)

Tabel 2. Struktur Populasi Sapi Madura Jantan di Sentra Sapi Sonok Kabupaten Pamekasan

\begin{tabular}{ccccccccc}
\hline \multirow{2}{*}{\begin{tabular}{l} 
Kenis \\
\cline { 2 - 9 }
\end{tabular}} & \multicolumn{9}{c}{ Umur Ternak Sapi Madura (Jantan) } \\
\cline { 2 - 9 } & $\mathrm{N}$ & $\%$ & $\mathrm{~N}$ & $\%$ & $\mathrm{~N}$ & $\%$ & $\mathrm{~N}$ & $\%$ \\
\hline Jantan & 4.456 & 27,07 & 5.775 & 35,05 & 6.237 & 37,87 & 16.468 & 100
\end{tabular}

Sumber : Dinas Ketahanan Pangan dan Peternakan (2017) 
Pada Tabel 1 dapat dilihat bahwa jumlah ternak sapi Madura betina adalah 58.646 ekor. Jumlah ternak sapi Sonok anak sebanyak 15.316 ekor $(26,11 \%)$, jumlah betina muda sebanyak 19.229 ekor $(32,78 \%)$ dan jumlah betina dewasa sebanyak 58.646 ekor $(41,09 \%)$. Persentase ternak betina dewasa lebih tinggi dibanding dengan struktur populasi yang lain, karena peternak sapi sonok memelihara ternak untuk menghasilkan anak yang akan dipelihara lagi atau dijual, maka peternak melakukan pemeliharaan betina dewasa untuk dijadikan induk. Para peternak tradisional lebih cenderung mempertahankan sapi betina muda untuk dipersiapkan sebagai replacement stock induk, sedangkan sapi jantan muda akan segera dijual ketika lepas sapih.

Pada Tabel 2 dapat dilihat bahwa jumlah ternak sapi Sonok jantan adalah 16.468 ekor. Jumlah ternak sapi Sonok anak sebanyak 4.456 ekor $(27,07 \%)$, jumlah jantan muda sebanyak 19.229 ekor $35,05 \%$ ) dan jumlah jantan dewasa sebanyak 58.646 ekor $(37,87 \%)$. Beberapa peternak yang tetap memelihara sapi jantan muda hingga dewasa, untuk dipersiapkan sebagai replacement stock pejantan bibit. Berdasarkan data di atas sapi Madura jantan dapat digunakan sebagai pejantan pemacek. Pejantan pemacek yang dimaksudkan dalam penelitian ini adalah sapi jantan keturunan dari indukan sapi Sonok unggul. Pejantan pemacek di sentra sapi Sonok masih digemari oleh peternak sebagai alternatif proses perkawinan. Proses perkawinan dilakukan secara kawin alam. Selain itu, pejantan pemacek yang memiliki kualitas yang baik akan dikrim ke Balai Inseminasi Buatan (BIB) untuk selanjutnya straw disebarkan lagi ke peternak melalui perkawinan inseminasi buatan (IB).

Perbandingan pedet jantan dengan pedet betina yaitu lebih besar pedet betina daripada pedet jantan, hal ini dapat disebabkan oleh angka kelahiran pedet betina lebih besar dibandingkan pedet jantan. Peluang anak sapi betina meningkat ketika melakukan IB atau kawin alam dalam rentan waktu 8 sampai 18 jam pertama dari permulaan estrus, sedangkan menunda waktu perkawinan (>18 jam) akan meningkatkan probabilitas anak sapi jantan (Tesfu et al., 2014).

\section{Penampilan Reproduksi}

Penampilan Reproduksi pada sapi Sonok meliputi: umur pertama kali kawin, service per conception, umur penyapihan, batas umur pemeliharaan, lama dalam pembiakan, open days, jarak kelahiran, umur beranak kedua, rasio kelahiran, cara kawin, dan kondisi induk setelah beranak. Pada Tabel 3 disajikan data mengenai penampilan reproduksi sapi Sonok di Kabupaten Pamekasan.

Tabel 3. Penampilan Reproduksi Sapi Sonok

\begin{tabular}{|c|c|c|}
\hline No. & Uraian & Rataan \\
\hline 1. & Umur pertama kali kawin (bulan) & $23,40 \pm 4,17$ \\
\hline 2. & Service per Conception (S/C) (kali) & $1,59 \pm 0,53$ \\
\hline 3. & Umur Penyapihan (bulan) & $5,20 \pm 0,69$ \\
\hline 4. & Batas umur pemeliharaan (tahun) & $11,37 \pm 1,08$ \\
\hline 5. & Lama dalam pembiakan (tahun) & $8,13 \pm 0,70$ \\
\hline 6. & Umur pertama beranak (bulan) & $33,92 \pm 3,88$ \\
\hline 7. & Open days (bulan) & $5,53 \pm 0,65$ \\
\hline 8. & Jarak beranak (calving interval) (bulan) & $14,50 \pm 1,83$ \\
\hline 8. & Umur beranak kedua (bulan) & $48,65 \pm 4,39$ \\
\hline \multirow[t]{3}{*}{9.} & Rasio Kelahiran (\%) & \\
\hline & - Jantan & $57,14 \%$ \\
\hline & - Betina & $42,86 \%$ \\
\hline \multirow[t]{3}{*}{10.} & Cara perkawinan & \\
\hline & - Kawin alam & $55 \%$ \\
\hline & - Inseminasi buatan & $45 \%$ \\
\hline \multirow[t]{4}{*}{11.} & Kondisi Induk setelah beranak & \\
\hline & - Gemuk & $22 \%$ \\
\hline & - Sedang & $64 \%$ \\
\hline & - Kurus & $14 \%$ \\
\hline
\end{tabular}

Sumber : Data Primer Diolah (2018) 


\section{Batas Umur Pemeliharaan dan Lama Dalam Pembiakan \\ Batas umur pemeliharaan merupakan batas} umur sapi digunakan sebagai tetua dalam wilayah pembiakan. Batas umur pemeliharaan tersebut berkaitan erat dengan lamanya sapi digunakan sebagai tetua dalam wilayah pembiakan. Batas umur pemeliharaan sapi sonok $11,37 \pm 1,08$ tahun dan lama dalam pembiakan $8,13 \pm 0,70$ tahun. Hal ini senada dengan penelitian Kutsiyah (2017) bahwa sapi Madura di Kepulauan Sapudi memiliki batas umur pemeliharaan sapi betina mencapai11,29 $\pm 4,92$ tahun dan lama pembiakan $8,8 \pm 3,56$. Hasil peneliitian Hardjosubroto et al. (1993) tentang sapi Madura menyebutkan bahwa betina 7,6 $6 \pm 0,3$ tahun atau beranak sampai 4,6 $6 \pm 0,3$ kali dan penelitian Kusuma et al. (2017) tentang sapi PO dengan batas umur pemeliharaan $8,8 \pm 3,56$ tahun. Jika diperhitungkan penelitian tentang sapi Sonok, antara umur pertama kali dikawinkan sampai saat diafkir dari pembiakan, berarti sapi betina dapat beranak sampai lima kali, tetapi jika dilihat atas dasar jumlah anak terlahir selama pembiakan diduga dipelihara sampai umur 7-8 tahun.

\section{Umur Pertama Beranak}

Umur pertama beranak sapi Sonok didapatkan hasil 33,92 $\pm 3,88$ bulan. Jika dibandingkan dengan penelitian Wisono (2015) pada sapi Madura di Kabupaten Pamekasan memiliki umur yang lebih tinggi yakni sebesar $34,63 \pm 2,46$ bulan dan lebih muda pada penelitian Kutsiyah (2017) pada sapi Madura di Kepualauan

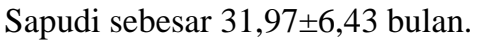

\section{Lama Kosong}

Lama kosong (open days) adalah jumlah periode dari melahirkan sampai ternak bunting kembali. Waktu terbaik untuk mengawinkan kembali pada sapi yaitu antara 60 sampai 90 hari setelah beranak (Toelihere, 1994). Nilai open days yang didapatkan pada penelitian ini sebesar $5,53 \pm 0,65$ bulan. Open days ini lebih lama dibandingkan laporan Wisono (2015) yakni di tiga kecamatan di Kabupaten Pamekasan yakni $122,18 \pm 24,96$ hari; $117,30 \pm 24,72$ hari dan $115,10 \pm 21,80$ hari. Tingginya nilai open days disebabkan salah satu faktor yakni masa penyapihan, semakin lama masa penyapihan maka semakin lama untuk mengawinkan kembali.

\section{Jarak Beranak}

Jarak beranak(calving interval) pada sapi Sonok memiliki nilai $14,50 \pm 1,83$ bulan. Calving interval (CI) ini lebih lama dibandingkan laporan Wisono (2015) yakni di tiga kecamatan di

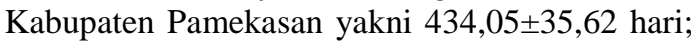

$384,97 \pm 27,45$ hari dan $374,32 \pm 17,85$ hari, sementara itu diperoleh informasi bahwa umur pertama beranak $31,97 \pm 6,43$ bulan. Penelitian Kutsiyah (2017) pada sapi Madura di Kepulauan Sapudi sebesar $14,56 \pm 2,15$ bulan juga menunjukkan waktu yang lebih lama, agar induk sapi dapat beranak setiap tahun sekali maka induk sapi harus sudah dikawinkan dan bunting maksimal 90 hari setelah beranak (Hafez, 1993). Lama CI dipengaruhi oleh lamanya penyapihan pedet dan S/C.

\section{Rasio Kelahiran}

Hasil penelitian menunjukkan bahwasanya rasio kelahiran jantan $57,14 \%$ dan betina $42,86 \%$, artinya rasio kelahiran pedet jantan lebih besar daripada pedet betina. Hal ini berbanding terbalik dengan Penelitian Kutsiyah (2017) pada sapi Madura di Kepulauan Sapudi sebesar Jantan $48,62 \%$ dan betina $51,38 \%$ artinya rasio kelahiran pedet betina lebih besar dari kelahiran pedet betina.

\section{Cara Perkawinan}

Para peternak cenderung menggunakan teknik kawin alami pada ternak sapi mereka karena tingkat keberhasilan terjadinya kebuntingan yang tinggi dan masih kurangnya kepercayaan masyarakat pada kualitas teknologi IB, kemudian dijumpai pada beberapa kasus peternak yang memilih kualitas pejantan pemaceknya sendiri karena berdasarkan silsilah. Hal ini ditunjukkan dengan keadaan dilapang, persentase pemilihan kawin ternak sebesar 55\% peternak lebih memilih kawin secara alami. Pemilihan kawin secara alami sapi Madura di wilayah konservasi Kepulauan Sapudi mencapai angka $100 \%$ pada penelitian Kutsiyah (2017).

\section{Kondisi Induk Setelah Melahirkan}

Kondisi induk setelah melahirkan sebagian besar dalam keadaan sedang atau tidak terlalu kurus maupun gemuk. Bobot badan induk berpengaruh sebesar $22 \%$ pada bobot lahir pedet jantan dan 24,6\% pada pedet betina (Muslim et al., 2013). Hasil yang didapat di lokasi penelitian bahwa kondisi induk setelah beranak gemuk sebesar $22 \%$, sedang sebesar $64 \%$, kurus sebesar $14 \%$. Kondisi sapi kurus berbanding terbalik pada Penelitian Kutsiyah (2017) pada sapi Madura di Kepulauan Sapudi bahwa kondisi gemuk 7,5\%, sedang $23,7 \%$ dan kurus $68,8 \%$. Kondisi induk setelah beranak ditentukan oleh manajemen pemeliharan sapi terutama suplai nutrisi pasca partus. Sapi Sonok merupakan sapi kontes jadi perfoman sangat diperhatikan oleh peternak. 


\section{Perhitungan Nilai Efisiensi Reproduksi}

Nilai Efisiensi Reproduksi (ER) sapi Sonok di Kabupaten Pamekasan yang diperoleh yaitu $90,51 \%$ tergolong relatif rendah, hal ini disebabkan karena umur pertama kali beranak yang masih terlalu lama jika dibandingkan dengan penelitian Kutsiyah (2017) pada sapi Madura di Kepulauan Sapudi didapatkan ER sebesar 93,21\%. Hal ini juga diperkuat dengan pendapat Sumadi (1993) dalam Kusuma et al. (2017) bahwa induk yang beranak pertama kali lebih dari 27 bulan akan mempunyai nilai ER kurang dari $100 \%$ dan sebaliknya apabila kurang dari 27 bulan maka nilai ER akan lebih dari $100 \%$. Usaha memperpendek jarak beranak dapat dilaksanakan dengan mempersingkat lama penyapihan. Penyapihan 105 hari dapat dilaksanakan dengan diikuti perbaikan manajemen terutama pakan (Sutanto, 2008).

\section{Pertambahan Alami (Natural Increase)}

Nilai Natural Increase (NI) diperoleh dengan mengurangkan tingkat kelahiran dengan tingkat kematian dalam suatu wilayah tertentu dan waktu tertentu yang biasanya penghitungannya diukur setiap tahun (Sumadi et al., 2001). Nilai NI sapi sonok pada penelitian ini sebesar $15,81 \%$ (Tabel 4). Hasil ini lebih rendah dibandingkan dengan hasil penelitian Kusuma (2017) pada sapi Ongole di Kabupaten Kebumen (2015) 18,76\%, pada sapi Madura di Kepulauan Sapudi oleh Kutsiyah (2017) 27,96\%, Samberi et al. (2009) 18,18\%, Aminudin (2005) 25,30\%, Sulistia (2007) 22,02\% dan sapi Madura di Pulau Madura tahun 1992 sebesar 18,26\% (Maskyadji, 1992). Nilai NI pada penelitian ini tergolong rendah, jika nilai NI berkisar antara 0 sampai 50\% tergolong rendah, $>50 \%$ sampai $80 \%$ tergolong sedang, dan diatas $80 \%$ tergolong tinggi.

Tabel 4. Perhitungan Natural Increase Sapi Sonok

\begin{tabular}{|c|c|c|}
\hline No. & Uraian & Rataan \\
\hline 1. & Persentase betina dewasa $(\%)$ & 65,63 \\
\hline 2. & Kelahiran pedet terhadap betina dewasa & 29,31 \\
\hline 3. & Kelahiran pedet terhadap Populasi $(\%)$ & 19,24 \\
\hline 4. & Tingkat kematian ternak terhadap populasi & 3,43 \\
\hline & Natural Increase & 15,81 \\
\hline
\end{tabular}

NI sapi Sonok di Kabupaten Pamekasan tersebut menunjukkan bahwa dengan $65,3 \%$ betina dewasa yang tersedia, diperoleh kelahiran pedet terhadap populasi sebesar 9,65\%, dengan tingkat kematian mencapai 3,43\%. Pertambahan populasi sapi Madura secara alami tersebut dapat menghasilkan tambahan pedet $29,31 \%$. Nilai NI tersebut menunjukkan bahwa pertambahan populasi sapi tergolong rendah (tinggi : 38,98 sampai 58,45\%; sedang: 19,49 sampai 38,97\%; rendah : 0 sampai 19,48\%). Rendahnya nilai NI disebabkan oleh rendahnya tingkat kelahiran dan tingginya tingkat kematian. Selain itu, pengalaman dan tingkat pendidikan peternak juga mempengaruhi nilai NI karena berkaitan dengan pemeliharaan, sehingga diperlukan pengkajian lebih lanjut penyebab dari rendahnya nilai NI tersebut.

\section{Perhitungan Nilai Net Replacement Rate}

Nilai net replacement rate (NRR) diperoleh dari perbandingan jumlah ternak muda calon pengganti dengan kebutuhan ternak pengganti per tahun dikalikan $100 \%$. Nilai NRR digunakan apakah jumlah kelahiran ternak dapat menutupi kebutuhan akan ternak pengganti agar populasi tetap konstan. Jika NRR <100\% maka kebutuhan ternak pengganti tidak terpenuhi, sebaliknya bila NRR >100\% maka kebutuhan ternak pengganti tercukupi (Samberi et al., 2010). Fungsi dari perhitungan NRR adalah untuk mengetahui kemampuan suatu wilayah untuk menyediakan kebutuhan ternak pengganti dalam suatu kurun waktu.

Nilai NRR sapi Sonok di Kabupaten Pamekasan tahun 2018 tersaji pada Tabel 5, bahwa nilai NRR sapi sonok di Kabupaten Pamekasan sebesar 101,48\%. Berdasarkan Hasil perhitungan ini maka di Kabupaten Pamekasan pada tahun 2018 terdapat surplus sapi sonok $101,48 \%$, oleh sebab itu Kabupaten Pamekasan masih berpeluang sebagai daerah pengembangan populasi ternak sapi Sonok dan sapi Madura pada umumnya guna peningkatan gizi masyarakat dan mempertahankan plasma nutfah sapi Madura. Nilai NRR $126,41 \%$ pada penelitian (Kutsiyah) 2017 sapi Madura induk di Kepulauan Sapudi menunjukkan angka surplus ternak yang lebih besar.

Tabel 5. Perhitungan Nilai Net Replacement Rate pada Sapi Sonok

\begin{tabular}{lr}
\hline \hline \multicolumn{1}{c}{ Uraian } & \multicolumn{1}{c}{ Rataan } \\
\hline Kebutuhan Pengganti & 8,12 \\
Ketersediaan & 8,24 \\
Net Replacement Rate & 101,48 \\
\hline
\end{tabular}




\section{Estimasi Potensi (Output)}

Potensi atau output sapi potong di suatu daerah adalah banyaknya ternak yang dapat dikeluarkan untuk dikirim atau dipotong dari suatu daerah tertentu tanpa mengganggu keseimbangan populasi ternak tersebut (Hardjosubroto, 1987 dalam Kusuma et al., 2017). Nilai output ternak sama dengan nilai NI maka dapat dikatakan terjadi keseimbangan populasi sehingga dalam kata lain nilai output populasi ternak yang paling optimal adalah sama dengan nilai NI. Apabila nilai output ternak lebih rendah daripada nilai NI maka akan terjadi peningkatan populasi, sedangkan jika nilai output lebih tinggi daripada nilai NI maka telah terjadi pengurasan populasi (Kusuma et al., 2017). Hasil perhitungan output sapi Sonok di wilayah Kabupaten Pamekasan (Tabel 6) menunjukkan nilai output $(8,24 \%)$ lebih tinggi daripada NI $(15,81 \%)$ sehingga wilayah Kabupaten Pamekasan masih dapat dikembangkan populasinya.

Tabel 6. Estimasi potensi atau output sapi Sonok di Kabupaten Pamekasan

\begin{tabular}{lr}
\hline \hline \multicolumn{1}{c}{ Uraian } & \multicolumn{1}{c}{ Rataan } \\
\hline Sex rasio kelahiran & \\
(jantan : betina) & $57,14: 42,86$ \\
Sisa replacement stock & 0,12 \\
Ternak afkir & 8,12 \\
\hline Total Output & $\mathbf{8 , 2 4}$ \\
\hline
\end{tabular}

Nilai output sapi sonok di wilayah Kabupaten Pamekasan pada penelitian ini lebih kecil daripada beberapa penelitian output sapi Bali atau sapi potong lainnya yaitu $13,11 \%$ (Samberi et al., 2010), Tonbesi (2008) sebesar $21,72 \%$, Aminuddin (2005) yakni mencapai $25,05 \%$. Namun nilai output ini lebih rendah bila dibandingkan dengan hasil penelitian Kusuma et al. (2017) sebesar 39,73\% dan penelitian sapi Madura di wilayah konservasi Kepulauan Sapudi sebesar $30,75 \%$. Perbedaan output ini diduga disebabkan oleh perbedaan ketersediaan pakan, tatalaksana pemeliharaan, iklim dan sosial ekonomi masyarakatnya (Sumadi et al., 2004). Faktor lainnya adalah sapi Sonok adalah sapi budaya/tradisi yang terdapat di Kabupaten Pamekasan sehingga sapi Sonok yang memiliki performa bagus akan tetap dipertahankan untuk menghasilkan bibit unggul karena pada setiap tingkat kontes sapi Sonok terdapat pembagian kelas yakni kelas induk, muda dan pedet.

\section{Dinamika Populasi Sapi Madura di Sentra Pembibitan Sapi Sonok}

Dinamika populasi dihitung berdasarkan data populasi beberapa tahun terakhir, sedangkan output populasi dihitung berdasarkan penampilan reproduksi ternak setahun terakhir. Hal ini menggambarkan bahwa penampilan reproduksi ternak setahun terakhir merupakan representasi terbaik penampilan reproduksi ternak selama beberapa tahun terakhir, karena dianggap dari tahun ke tahun upaya perbaikan penampilan reproduksi selalu dilakukan oleh peternak sehingga penampilan reproduksiternak setahun terakhir dapat dijadikan dasar koefisien teknis yang digunakan untuk mengestimasi perkembangan output populasi ternak beberapa tahun ke depan (Kusuma et al, 2017).

Dinamika populasi sapi Madura di sentra pembibitan sapi Sonok di Kabupaten Pamekasan dalam kurun waktu tahun 2013 sampai tahun 2017 disajikan pada Tabel 7. Salah satu yang menyebabkan kenaikan populasi setiap tahunnya adalah motivasi peternak untuk melestarikan budaya sapi Sonok, mempertahankan plasma nutfah sapi Madura, memeprtahankan populasi sapi induk/dewasa dan pencegahan pemotongan pada betina produktif, dukungan pemerintah untuk meningkatkan populasi dalam beberapa program yakni Intan Satu Saka dan Upsus Siwab. Faktor lain yang mempengaruhi adalah harga jual pedet sapi sonok yang tinggi berkisar $\mathrm{Rp}$ 5.000.000 - Rp 20.000.000, sehingga motif pemeliharan semakin meningkat. Dinamika populasi sapi Sonok di Kabupaten Pamekasan dalam kurun waktu tahun 2013 sampai tahun 2017 mengalami peningkatan rerata setiap tahun sebesar 7,98\%

Tabel 7. Dinamika Populasi Sapi Sonok Kurun Waktu 2013-2017

\begin{tabular}{lrrr}
\hline \multirow{2}{*}{ Tahun } & \multirow{2}{*}{$\begin{array}{c}\text { Populasi } \\
\text { (ekor) }\end{array}$} & \multicolumn{2}{c}{ Perkembangan } \\
\cline { 3 - 4 } & 56.562 & (ekor) & \multicolumn{1}{c}{$(\boldsymbol{\%})$} \\
\hline 2013 & 57.239 & 677 & - \\
2014 & 58.229 & 990 & 1,97 \\
2015 & 74.107 & 15.878 & 27,26 \\
2016 & 74.815 & 708 & 0,96 \\
2017 & &
\end{tabular}

Berdasarkan kenaikan rerata dan persamaan regresi $\mathrm{Y}=\mathrm{ax}+\mathrm{b}$ dari hasil analisis time series data tahun 2013 sampai 2017, maka diperoleh persamaan $Y=7810 x-37834$ selanjutnya digunakan untuk mengestimasi populasi sapi Sonok di Kabupaten Pamekasan tahun 2018 sampai tahun 2022 yang disajikan pada Tabel 8. 
Tabel 8. Estimasi Dinamika Populasi Sapi Sonok Kurun Waktu 2018 - 2022

\begin{tabular}{lccr}
\hline \hline Tahun & $\begin{array}{c}\text { Populasi } \\
\text { (ekor) }\end{array}$ & \multicolumn{2}{c}{ Perkembangan } \\
(ekor) & $(\boldsymbol{\%})$ \\
\hline 2018 & 84.694 & 9.879 & 13,20 \\
2019 & 92.504 & 7.810 & 9,22 \\
2020 & 100.314 & 7.810 & 8,44 \\
2021 & 108.124 & 7.810 & 7,78 \\
2022 & 115.934 & 7.810 & 7,22 \\
\hline Rerata & $\mathbf{1 0 0 . 3 1 4}$ & $\mathbf{7 . 8 1 0}$ & $\mathbf{9 , 1 7}$ \\
\hline
\end{tabular}

\section{SIMPULAN DAN SARAN}

\section{Simpulan}

Penampilan reproduksi sapi Sonok di Kabupaten Pamekasan sudah cukup baik.Umur

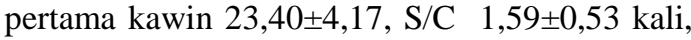
jarak beranak $14,50 \pm 1,83$ bulan, dan nilai efisiensi reproduksi (ER) $90,51 \%$. Nilai natural increase (NI) sapi Sonok di Kabupaten Pamekasan tahun 2014 sebesar 9,55\%, nilai net replacement rate (NRR) sapi Sonok sebesar $101,48 \%$. Hasil estimasi output sapi Sonok 8,24\%. Dinamika populasi sapi Madura di sentra pembibitan sapi Sonok Kabupaten Pamekasan dalam kurun waktu tahun 2013 sampai 2017 mengalami kenaikan rerata setiap tahun sebesar 7,98\%. Hasil estimasi dinamika populasinya tahun 2018 sampai 2022 diperkirakan akan mengalami kenaikan per tahun sebesar 9,18\%, sehingga disimpulkan bahwa sapi Sonok di Kabupaten Pamekasan masih berpotensi untuk meningkatkan populasi, yakni nilai output $(5,06 \%)$ lebih rendah daripada NI $(15,81 \%)$.

\section{Saran}

Perlu adanya pencatatan atau perhitungan pertumbuhan alami (natural increase) dan output populasi ternak dalam suatu wilayah yang dilakukan secara kontinyu setiap tahun sehingga perkembangan populasi ternak dapat diketahui dan bisa digunakan sebagai pedoman atau acuan dalam melakukan perencanaan program pengembangan ternak di wilayah tersebut.

\section{DAFTAR PUSTAKA}

Aminudin, A. 2005. Estimasi Dinamika Populasi dan Potensi Sapi Bali di Provinsi Sulawesi Tenggara. Tesis. Program Pascasarjana Peternakan. Universitas Gadjah Mada. Yogyakarta.

Hafez dan Jaenudeen. 1993. Cattle and Buffalo Reproductive Cycle dalam Reproduction In Farm Animal. 6th edition. Lea and Febinger. Philadelphia.
Hardjosubroto, W., B. Endang, dan Z. Sidqi. 1993. Kapasitas suplai sapi Madura dari pulau Madura. Pros. Pertemuan Ilmiah Hasil Penelitian dan Pengembangan Sapi Madura Sub Balitnak Grati Sumenep: 198-210.

Kusuma, S.B., N. Ngadiyono, dan Sumadi. 2017. Estimasi dinamika populasi dan penampilan reproduksi sapi Peranakan Ongole di Kabupaten Kebumen Provinsi Jawa Tengah. Bull. Anim. Sci. 41(3): 230242

Kutsiyah, Farahdilla. 2015. Sapi Sonok \& Sapi Karapan Budaya Ekonomi Kreatif Masyarakat Madura. Plantaxia. Yogyakarta.

Kutsiyah, F. 2017. Dinamika Populasi dan Produktivitas Sapi Madura di Wilayah Konservasi Pulau Sapudi. Sains Peternakan: Jurnal Penelitian Ilmu Peternakan. 15(2): 70-77

Maskyadji, Z.Z.S.A. 1992. Pertumbuhan dan OutputSapi Madura di Pulau Madura. Tesis. Program Pascasarjana. Universitas Gadjah Mada.Yogyakarta.

Muslim, K. N., H. Nugroho, dan T. Susilawati. 2013. Hubungan antara bobot badan induk dan bobot lahir pedet sapi Brahman Cross pada jenis kelamin yang berbeda. J. IlmuIlmu Pet. 23: 18-24.

Musofie, A. Niniek, KW dan A.A. Yusran. 1992. Respon Sapi Madura Terhadap Pemberian Pakan. Proceding Pertemuan Ilmiah Hasil Pengembangan Sapi Madura. Sumenep Sub Balai Penelitian Tenak Grati. Pasuruan.

Samberi, K.Y., N. Ngadiyono, dan Sumadi. 2010. Estimasi dinamika populasi dan produktivitas sapi Bali di Kabupaten Kepulauan Yapen, Propinsi Papua. Buletin Peternakan 34: 169-177.

Sumadi, W. Hardjosubroto, N. Ngadiyono, dan S. Prihadi. 2001. Potensi Sapi Potong di Kabupaten Sleman. Analisis dari Segi Pemuliaan dan Produksi Daging. Yogyakarta.

Sulistia, I. 2007. Estimasi Natural Increase dan Pola Pemeliharaan Sapi Bali di Kabupaten Penajam Paser Utara, Kalimantan Timur. Skripsi. Fakultas Peternakan Universitas Gadjah Mada. Yogyakarta.

Sutanto, A. 2008. Pengaruh Bangsa, Jenis Kelamin dan Periode Penyapihan terhadap Pertumbuhan Pedet Dan Reproduksi Sapi Induk di BPTU Sapi Dwiguna dan Ayam Sembawa Sumatera Selatan. Tesis. Pasca Sarjana, Fakultas Peternakan, Universitas Gajah Mada. Yogyakarta. 
Tesfu, F., B. Gebrekidan, and B. Afera. 2014. Assessment and comparison of sex ratio following artificial insemination and natural mating in small scale and modern dairy cattle farms in mekelle. J. Reprod. Infertility 5: 58-64.

Toelihere, M. R. 1994. Fisiologi Reproduksi pada Ternak. Angkasa. Bandung.

Tonbesi, T.T. 2008. Estimasi Potensi dan Kinerja Sapi Bali di Kabupaten Timor Tengah Utara Propinsi Nusa Tenggara Timur. Tesis. Pascasarjana Universitas Gadjah Mada. Yogyakarta.

Wisono, D.A. 2015. Performan Reproduksi Sapi Madura Induk dengan Perkawinan Inseminasi Buatan di Kabupaten Pamekasan. Thesis, Universitas Brawijaya. 